\title{
„Chcę nadmienić, że nie byłem uświadomiony i wykonywałem zadanie jako żołnierz Armii Krajowej”. O wymordowaniu ukrywających się pod Racławicami Żydów przez kompanię miechowskiej AK
}

W końcu listopada 1943 r. we wsi Rędziny-Borek (gmina Racławice, pow. Miechów) do stojącego pod lasem domu Franciszka Szycha zaczęła dobijać się grupa uzbrojonych ludzi. Gospodarza nie było w domu, a jego żona odmówiła otwarcia drzwi nieznajomym. Jak zeznał po wojnie Szych, „banda wyrwała okna i drzwi i wtargnęła do mieszkania. W mieszkaniu pytali się żony gdzie są żydzi”. Sterroryzowana kobieta wskazała napastnikom zamaskowane drzwi do komory, w której istotnie ukrywało się wówczas sześcioro Żydów. Na samym początku - wskutek odmowy wyjścia z ukrycia - zginął doktor Szlesinger, dentysta z pobliskich Działoszyc. Pierwsza kula wystrzelona przez napastników zmiażdżyła mu kolano; drugą kulą został dobity, gdy już leżał na ziemi. Pozostali Żydzi - czterech mężczyzn i jedna kobieta - wyszli z komory i zostali poddani gruntownej rewizji. Otaczało ich co najmniej sześciu mężczyzn uzbrojonych w karabiny i rewolwery. Odebrano im wszystko, co mieli przy sobie: kosztowności, pieniądze (jak się później okazało, było tego razem 130 dolarów i 10 tysięcy złotych), portfele, zegarki i ubrania. Przeczuwając nadchodzący mord, Żydzi zaczęli błagać o litość. Oddajmy znów głos Franciszkowi Szychowi: „żona opowiadała mi, że żydzi ci bardzo się prosili by im darowano życie i są oni niewinni nic, na co odpowiedzieli im właśnie członkowie bandy: »cóż wam po życiu kiedy już pieniędzy nie macie«. Błagania nie zrobiły na napastnikach najmniejszego wrażenia. Obrabowanych przesłuchano, bezskutecznie dopytując się o innych ukrytych Żydów. Po chwili ustawiono ich pod ścianą, wewnątrz domu, i zabito strzałami w tył głowy. Z trupów ściągnięto ubrania, tak że zwłoki pozostawiono prawie nagie. Na odchodnym napastnicy polecili gospodyni zakopać trupy, po czym zniknęli w lesie.

Egzekucja w Rędzinach-Borku sama w sobie niczym na pozór nie różni się od mnóstwa innych mordów dokonanych na okupowanych ziemiach polskich przez znanych bądź też nieznanych sprawców na ukrywających się Żydach w latach 1942-1945. Od lata 1942 r., gdy „ostateczne rozwiązanie kwestii żydowskiej” weszło w końcową fazę, setki tysięcy polskich Żydów zaczęły w panice podejmować próby ratunku. Najczęściej budowano sobie schronienia, bunkry i kryjówki we- 
wnątrz gett, licząc na przeczekanie pierwszej fazy akcji likwidacyjnej. W getcie warszawskim powstała na ten temat nawet piosenka:

Wszyscy Niemcy dobrze wiedza,

że w kryjówkach Żydzi siedza,

lub tez, jako aryjczycy,

zaludniają część stolicy,

Więc budujmy sobie schrony

to najlepszy znak ochrony

schron jest lepszy niż Poniatów

lub kryjówka u Polaków... ${ }^{1}$

Tropieniem kryjówek zajmowali się niemieccy żandarmi, oddziały likwidacyjne policji, żydowscy OD-mani, granatowi policjanci oraz jakaś część okolicznej ludności, o czym wspominają liczne relacje ${ }^{2}$. W Małopolsce wyjątkowo niechlubna rola w likwidacji gett i w wyłapywaniu Żydów przypadła polskim junakom ze Służby Budowlanej (Baudienst).

Ci Żydzi, którym udało się opuścić getto, musieli zdać się na pomoc ludzi przebywających „po aryjskiej stronie”. Ich przychylność zapewniano sobie zazwyczaj za pomocą sowitych opłat; rzadziej można było liczyć na bezinteresowności i współczucie gospodarzy. Wraz z likwidacją gett nastał czas polowania na Żydów. Niemcy, świadomi liczby uciekinierów, z jednej strony zaostrzyli kary grożące za ukrywanie i niesienie pomocy Żydom, a z drugiej - wprowadzili system skromnych nagród i amnestii dla tych, którzy przyczynili się do schwytania „wrogów rasy”. Nagrody z reguły były wypłacane w naturze: mogło to być parę kilo cukru, litr wódki, ewentualnie ubrania zdejmowane z Żydów przed egzekucją. W miastach „wpadki” Żydów najczęściej spowodowane były donosami, wobec czego samego mordu dokonywali sprowadzeni w ten sposób niemieccy policjanci. Nieco inaczej rzecz się miała na terenach wiejskich. Tu również donosy grały ogromną rolę, lecz często mordowaniem Żydów trudniła się polska „granatowa” policja. Niejednokrotnie zresztą mordercy w granatowych mundurach tłumaczyli swe czyny chęcią ochrony miejscowych mieszkańców, których życie byłoby zagrożone, gdyby Żydzi wpadli w ręce niemieckiej żandarmerii. W wielu jednak wypadkach Żydów ukrywających

${ }^{1}$ Fragment piosenki śpiewanej w getcie warszawskim, wkrótce przed jego ostatecznac likwidacją. Pierwsze transporty Żydów z getta warszawskiego do obozu w Poniatowej odeszły w lutym-marcu 1943 r. Archiwum Yad Vashem (dalej: YVA), zespół E/438, Relacja Poli Rotszyld, s. 97.

${ }^{2}$ Z dzienników napisanych przez Polaków można choćby odnotować: Z. Klukowski, Zamojszczyzna, 1918-1943, Warszawa 2008, s. 372 i dziennik łukowskiego nauczyciela S. Żemińskiego, AŻIH, zespół 302/30, nota z dnia 16 listopada 1942, s. 10. Dzienników, relacji i wspomnień żydowskich poświęconych w części lub w całości temu tematowi jest zbyt wiele, aby je tu wyliczać. Warto jedynie odnotować istnienie ogromnych kolekcji wspomnień żydowskich zgromadzonych z Yad Vashem (zespół 0\33 i O3) oraz w Żydowskim Instytucie Historycznym (zespoły 301 oraz 302). 
się na wsi mordowano własnymi rękami, nie uciekając się do informowania władz. Mordowały bliżej niezidentyfikowane „bandy”, mordowali sami gospodarze, mordowano też grupowo, z polecenia sołtysa. Mordy popełniane przez gospodarzy zazwyczaj wiązały się z wyczerpaniem się zasobów pieniężnych ukrywających się Żydów. W odróżnieniu od miast, sprawa ukrycia zwłok nie przedstawiała na wsi żadnego problemu. Choć obowiązywał przy tym pewien rytuał - o czym później.

Wydarzenia w Rędzinach-Borku, z listopada 1943 r., na pierwszy rzut oka wpisują się właśnie $w$ taki schemat działań: jedna z licznych band rabunkowych, zwiedziawszy się o miejscu pobytu Żydów, postanawiła dokonać rabunku na bezbronnych, a następnie ich wymordowała. Życie ludzkie, a już szczególnie życie żydowskie, nie przedstawiało w końcu wówczas większej wartości. Jednak ani gospodarz, ani schowani u niego Żydzi nie zdawali sobie sprawy, że atak na dom nie był akcją leśnej bandy, lecz ukoronowaniem starannie zaplanowanego manewru bojowego miechowskich struktur AK.

\section{Źródła}

Gros prezentowanych tu dokumentów pochodzi z opasłej teczki dotyczącej procesu toczonego przed Sądem Apelacyjnym w Krakowie w latach 1949-19503. Nie ulega wątpliwości, że materiały dochodzeniowo-śledcze $\mathrm{z}$ tego okresu należy traktować z wielką ostrożnością. Nie znaczy to jednak, że są dla historyka pozbawione wartości. Tak jak bogate akta sądów niemieckich czy też akta gestapo (zespoły takie można nazwać „archiwami represji”) legły u podstaw wielu studiów o zasadniczym znaczeniu dla poznania hitlerowskiego totalitaryzmu, tak i omawiane tu źródła mają podstawowe znaczenie dla zrozumienia niektórych co bardziej tragicznych aspektów tego okresu. W wypadku dochodzeń o mordowanie i wydawanie Żydów śledczym zazwyczaj nie zależało na rozwijaniu ponad miarę wątków antyżydowskich, których nagłaśnianie nie leżałoby - na tym etapie - w interesie władz. Oskarżenia AK-owców o działania antyżydowskie mogłyby - w pewnych odłamach społeczeństwa - wywołać skutek przeciwny do tego, na jakim władzom zależało. Rzecz symptomatyczna: pomimo zeznań obciążających wyższych przełożonych, złożonych w śledztwie przez głównego oskarżonego, dochodzenie nie wyszło poza bezpośrednich uczestników mordu.

\section{Ofiary}

O ofiarach mordu w Rędzinach-Borku wiemy niewiele. Jak wynika z bardzo fragmentarycznej wiedzy ukrywającego Żydów gospodarza, większość, jeżeli nie wszyscy, pochodziła z pobliskich Działoszyc. Pierwsza akcja likwidacyjna w Działoszycach nastąpiła 2 września 1942 r., kiedy to opróżniono getto, a jego mieszkań-

${ }^{3}$ Archiwum Państwowe w Krakowie (dalej: APKr), Sąd Apelacyjny w Krakowie (dalej: SAKr), teczka 1029\IV k\180\50. 
ców wywieziono do Bełżca ${ }^{4}$. Podczas brutalnej akcji przeprowadzonej przez Niemców, polską „granatową” policję i junaków z Baudienstu zginęło ok. dwóch tysięcy ludzi. Niedobitki żydowskich mieszkańców Działoszyc wróciły do opuszczonych i okradzionych domów w kilka tygodni po pierwszej ,akcji”. Zachował się następujący opis ówczesnych wydarzeń: „Niemcy zjechali do miasteczka jak huragan, na motocyklach z przyczepami. Chaim-Lezer wszedł na strych zobaczyć co się dzieje. Z tego to punktu obserwacyjnego ujrzał junaków (polscy gangsterzy, którzy pomagali Niemcom w przeszukiwaniach domów gdyż wtedy mogli rabować), którzy otoczyli miasto. Junacy, uzbrojeni w łopaty, łomy i szpadle, ustawili się w kordon, stojąc w odstępach co 3-4 metry, tworząc w ten sposób istny mur. Nie zdziwiło nas to, że junacy ochoczo podjęli się wykonywać brudną robotę za Niemców ${ }^{5}$. [...] Nieco później Żydów popędzono z Działoszyc w stronę Miechowa, gdzie kazano im się zatrzymać na podmokłej łące. Teren znów obstawili polscy junacy z Baudienstu, uniemożliwiając Żydom ucieczkę"6.

Druga i ostatnia „akcja” w Działoszycach nastąpiła w październiku 1942 r. Wtedy też pierwszy zbieg pojawił się w domu Franciszka Szycha. Z Działoszyc do Rędzin-Borku w linii prostej jest około dziesięciu kilometrów. Drogą - nieco więcej. Według gospodarza, który za pieniądze zgodził się ukrywać Żydów, jako pierwszy pojawił się doktor Szlesinger (lub Schlezingier), dentysta z Działoszyc. W ślad za nim do kryjówki u Szycha przybył niejaki Przewoźnik, właściciel fabryki mydła w Działoszycach, wraz z żoną. Przypuszczalnie chodzi tu o Józefa Przewoźnika i jego żonę, Minę Ptasznik . W kryjówce znaleźli się również dwaj bracia Kołatacze (też z Działoszyc) - najpewniej chodzi tu o Nachuma oraz Arona Kołataczy, oraz jeszcze jeden mężczyzna, którego nazwiska nie udało się ustalić.

\section{Wpadka i mord}

Trudno powiedzieć, w jaki sposób sąsiedzi dowiedzieli się o Żydach przechowywanych w kryjówce u Szycha. Z zeznań oskarżonych i świadków dowiadujemy się jednak, że na pewien czas przed listopadową masakrą ktoś złożył na ten temat donos do sołtysa. Sołtys powiadomił władze niemieckie i niebawem dom Szycha został otoczony i przeszukany przez policję (przypuszczalnie przez żandarmerię). Wokół domu trzymali wartę miejscowi chłopi, chcąc zapobiec ewentualnej ucieczce poszukiwanych. Nie wiadomo, czy chodziło tu o zwykłych gapiów, czy też raczej o gromadzkich „dziesiętników”. Z reguły żandarmeria, idąc na przeciwżydowskie akcje, mobilizowała chłopów do pomocy. Najczęściej rekrutowano ich spośród

${ }^{4}$ O zagładzie Działoszyc oraz o ukrywaniu się w okolicy zob. Eliahu Raziel (Rozdzial), Alone and in Hiding, maszynopis, archiwum United States Holocaust Memorial Museum (USHMM), 1994.

${ }^{5}$ J.E. Tenenbaum, Legacy and Redemption. A Life Renewed, United States Holocaust Memorial Museum, Waszyngton, 2005, s. 105.

${ }^{6}$ J.E. Tenenbaum, op. cit., s. 110.

${ }^{7}$ Nazwiska pochodzą w centralnego rejestru archiwum Yad Vashem „Hall of Names”. 
członków stałych straży wiejskich ${ }^{8}$, tzw. dziesiętników, bądź też „zakładników” chłopów wyznaczanych okresowo przez sołtysa, którzy musieli stawić się na każde żądanie pod groźbą surowych sankcji. W tym wypadku kryjówka była jednak tak dobrze zamaskowana, że rewizja nie przyniosła skutków - Żydów Niemcy nie znaleźli. O ile Niemcy uznali sprawę za zamkniętą, o tyle dla Szycha nadszedł szczególnie niebezpieczny okres. Dalsze ukrywanie Żydów w sytuacji, w której cała wioska była świadoma ciążących na Szychu podejrzeń, stawało się z dnia na dzień coraz bardziej niebezpiecznym zajęciem. Przed gospodarzem stały wobec tego następujące możliwości: wymówienie ukrywanym dalszej gościny, wydanie ich w ręce Niemców, wydanie ich w ręce „granatowej” policji, wymordowanie ich na własną rękę, bądź też wezwanie na pomoc lokalnego „podziemia”. Na podstawie analizy licznych procesów „sierpniowych” można stwierdzić, że wydawanie Żydów w ręce Niemców było - na tym etapie - sprawą dość ryzykowną. Niemcy ofiarowywali co prawda amnestie (lub nawet nagrody) dla ukrywających, którzy wydawali swoich „podopiecznych”, ale nie jest pewne, jak zareagowaliby na meldunek płynący od kogoś, na kogo już wcześniej składano donosy i kto był już celem dochodzenia. Podobne zastrzeżenia dotyczyć mogły prób wydania Żydów w ręce polskiej policji. „Granatowi” dość często i chętnie brali na siebie „likwidację” ukrywanych Żydów, ale zależało to w znacznym stopniu od stosunków lokalnych. W okolicach Tarnowa np. mordy na ukrywających się Żydach dokonywane przez „granatowych” policjantów tłumaczono „chęcią ochrony wspólnoty gromadzkiej przed ewentualną akcją niemiecką”. Przede wszystkim jednak chodziło tu o szansę rabunku - „granatowi” policjanci w sposób szczególnie skuteczny zajmowali się wymuszaniem pieniędzy i kosztowności od złapanych Żydów ${ }^{9}$. Innymi słowy, w zgodzie z tą logiką, mordując Żydów, „granatowy” policjant uniemożliwiał Niemcom wykrycie tożsamości Polaków oferujących im dotychczas gościnę i tym samym ratował całą wioskę przed odwetowymi akcjami terroru ze strony okupanta. Zasadnicze znaczenie w postępowaniu „granatowej” policji miało wzajemne zaufanie między sołtysem a komendantem posterunku oraz bliskość żandarmów niemieckich. Jeżeli chodzi o wymówienie Żydom dalszej gościny - wyjście z pozoru najprostsze - to wymagało ono pewnej współpracy ze strony eksmitowanych. A o tę w końcu 1943 r. było trudno. Los Żydów wyrzucanych z kryjówek w tym okresie był zazwyczaj tragiczny. Sytuację dodatkowo komplikował fakt, że błąkający się po okolicy Żydzi prędzej lub później wpadliby w ręce Niemców lub rodzimych złoczyńców, ujawniając tożsamość ukrywających Polaków. W obu wypadkach konsekwencje dla ukrywających mogły być groźne; ze strony Niemców groziły represje za łamanie rozporządzeń „o ograniczeniu prawa pobytu Żydów”, natomiast lokalni bandyci mogli dokonać najazdu

\footnotetext{
${ }^{8}$ Zgodnie z niemieckimi zarządzeniami każda wioska musiała wystawić określoną ilość wartowników nocnych, którzy mieli ubezpieczać mieszkańców przed napadami bandytów, zbiegłych jeńców, partyzantów czy też innego niepożądanego elementu.

${ }^{9}$ Szczegółowy opis tej „praktyki policyjnej” można znaleźć we wspomnieniach „granatowego" policjanta recenzowanych przeze mnie w tym tomie - zob. T.S. Krasnodębski, Policjant konspiratorem. Szesnaście lat na muszce gestapo i bezpieki, Kraków 2008.
} 
na dom w poszukiwaniu bogactw rzekomo pozostawionych przez Żydów. Jeszcze inne z możliwych rozwiązań - wymordowanie uciążliwych Żydów we własnym zakresie - w omawianym przypadku raczej nie wchodziło w rachubę. Wskazywał na to prosty stosunek sił: w kryjówce u Franciszka Szycha ukrywało się sześć osób (w tym pięciu dorosłych mężczyzn), które z całą pewnością drogo sprzedałyby własne życie.

W listopadzie 1943 r. Bolesław Krzyszkiewicz ps. „Regiński” rozpoczął przygotowania do likwidacji Żydów znajdujących się na jego terenie ${ }^{10}$. Porucznik rezerwy „Regiński” był komendantem placówki AK w Kalinie Wielkiej. Placówka ta, nosząca kryptonim „Kot”, już w początkach 1944 r. miała oficjalnie wejść w skład 112 miechowskiego pułku piechoty AK. Jej stan osobowy wynosił ok. 250 ludzi. Uzbrojenie składało się z 2 PIAT-ów, 6 stenów, kilku pistoletów ręcznych, kbk, granatów oraz zapasów amunicji. Tak przynajmniej wynika z powojennej relacji Krzyszkiewicza. Zresztą relacja ta dotyczyła 1944 r., można więc przypuszczać, że siła ognia, którą dysponowali żołnierze „Regińskiego” w końcu 1943 r., była nieco mniejsza ${ }^{11}$. Warto tu odnotować, że w kronice wydarzeń 106 Dywizji wśród akcji sabotażowo-dywersyjnych Placówki AK „Kot” z listopada 1943 r. odnotowano udany atak na gorzelnię oraz rozbrojenie żołnierza niemieckiego podróżującego koleją. W kronice tej ataku na dom Franciszka Szycha nie odnotowano ${ }^{12}$. Według jednego $z$ oskarżonych to nie ktoś inny, lecz sam gospodarz miał się zwrócić do znajomych z konspiracji, aby pomogli mu usunąć kłopotliwych Żydów: „Nadmieniam przy tym, że jest mi wiadomym od ludzi z Kaliny Małej”, zeznawał uczestnik akcji, „że Szych zdradził tych żydów i domagał się by ich zlikwidować, ponieważ obawiał się żeby Niemcy go nie zastrzelili oraz jego rodziny". Wedle Krzyszkiewicza natomiast rozkaz likwidacji Żydów przyszedł „Z góry” i miał mieć formę ustną. Uzasadnieniem egzekucji miały być rabunki dokonywane na miejscowej ludności przez uzbrojonych Żydów. Dalsze działania przybrały charakter czysto wojskowy, a sama akcja likwidacyjna została przeprowadzona zgodnie z protokołem i w ramach schematu działania zgodnego ze szkoleniami Armii Krajowej. Wpierw Krzyszkiewicz zażądał posiłków ze strony „Żbika” - dowódcy Grupy Dywersyjnej w powiecie miechowskim ${ }^{13}$.

${ }^{10}$ Bolesław Krzyszkiewicz ps. „Regiński” jest również wspomniany jako uczestnik walk z Niemcami latem 1944 r. Odnotowano jego rolę jako dowódcy kompanii batalionu I $\backslash 112$ AK. B.M. Nieczuja-Ostrowski, Rzeczpospolita partyzancka. Inspektorat „Maria” w walce, Warszawa 1991, s. 116.

${ }^{11} \mathrm{~W}$ pracy poświęconej dziejom 106 DP AK czytamy następującą charakterystykę ppor./ kpt. rez. Bolesława Krzyszkiewicza ps. „Regiński”: „bohater i męczennik, po wojnie niewinnie oskarżony, skazany na dożywocie, przesiedział 16 lat w więzieniu PRL, maltretowany w śledztwie przez UB”. Zob. B.M. Nieczuja-Ostrowski, op. cit., s. 96. O partyzanckich akcjach Krzyszkiewicza pisze też Józef Guzik: W obronie miechowskiej wsi, 1939-1945, Warszawa 1981, s. 178.

${ }^{12}$ Zob. B.M. Nieczuja-Ostrowski, Inspektorat AK „Maria” w walce, t. 2, Elbląg 2001, s. 381.

${ }^{13}$ Ppor. rez. Stanisław Jazdowski. O „Żbiku” - bardzo niepochlebnie - pisze Bogusław Hojnacki w książce Wyjść z mroku, Warszawa 1980, s. 159-161. 
„Żbik” dosłał pięciu ludzi wraz z uzbrojeniem, a Stanisław Ch., dowódca placówki AK z Książa Wielkiego, zjawił się osobiście, w towarzystwie trzech uzbrojonych żołnierzy. Punkt zborny wyznaczono w lesie, koło Kaliny Wielkiej, skąd „marszem ubezpieczonym" wzmocniona kompania udała się do Rędzin-Borku. Na zbiórce Krzyszkiewicz rozdał żołnierzom swojej kompanii wcześniej przygotowaną broń i wtajemniczył ich, że idą „strzelać Żydów, którzy są w domu Szycha”. Następnie zarządzono wymarsz. Do Borku z Kaliny nie jest daleko - wystarczy wspiąć się na strome wzgórze, a potem przejść dalej lasem, już po równym terenie. Po przybyciu na miejsce część kompanii otoczyła dom, inni stali pod lasem na czatach, a wcześniej wyznaczony pluton egzekucyjny wtargnął do domu. Dalszy ciąg ataku na dom opisywał jeden z uczestników akcji: „W tym to czasie dwóch nieznanych mi osobników otworzyło drzwi do komory, w której znajdował się jeden żyd, reszta zaś była ukryta. W drzwiach stanąłem ja i »Regiński«, który wydał rozkaz żydowi by podniósł ręce do góry, a gdy ten nie chciał tego uczynić, »Regiński« wydał mi polecenie żeby strzelać, ja wówczas dałem strzał ostrzegawczy, a gdy nie podniósł rąk do góry, dałem drugi strzał w kolano i żyd ten został zastrzelony, reszta żydów i jedna żydóweczka wyszli z kryjówki. Dwaj nieznani mi całkiem członkowie AK wyprowadzili tych żydów do sieni i przeprowadzili rewizję, podczas której zostały im zabrane portwele [sic!], zegarki, obrączki i pierścionki, rzeczy te zabrali ci właśnie dwaj nieznani mi całkiem osobnicy. Gdy zostali zrewidowani z sieni zostali wyprowadzeni z powrotem do komory i ustawieni twarzą do ściany. Wówczas »Regiński« z pistoletem stanął pierwszy obok dwóch nieznanych mi osobników, ja byłem czwarty, a Wesołowski piąty, a my byliśmy z karabinami, ci dwaj zaś nieznani mi osobnicy byli z pistoletami. Gdy wszystko było gotowe, żydzi ci prosili się i mówili w te słowy: »darujcie nam życie« lecz pomimo to »Regiński« dał pierwszy strzał w tył głowy żydowi, a następnie wszyscy z kolei strzelaliśmy z tyłu w głowy” [...] Chcę przy tym nadmienić, że nie byłem uświadomiony, co czyniłem gdyż dowódca, jakim był »Regiński« dał polecenie i wykonywałem [je] tylko jako żołnierz Armii Krajowej” - kończył swoje zeznanie żołnierz Placówki „Kot”. Po egzekucji „Regiński” wydał żonie Szycha polecenie zakopania zwłok. Trzeba nadmienić, że mordowanych Żydów chowano na wsiach polskich w różnych miejscach i wiązał się z tym pewien protokół. Najogólniej rzecz biorąc - odległość miejsca pochówku od chaty była odwrotnie proporcjonalna do zaufania, jakim cieszyli się ukrywający we wioskowej wspólnocie. W wypadku ludzi „przyłapanych” na ukrywaniu Żydów ofiary nakazywano zakopywać w bezpośredniej bliskości domu. W skrajnych wypadkach zwłoki zakopywano bezpośrednio pod klepiskiem, w chałupie, niejako „za karę”. Niekiedy zamordowanych Żydów zakopywano pod oknami. Stanowiło to wyraz głębokiej dezaprobaty ze strony wspólnoty gromadzkiej w stosunku do Polaków ukrywających Żydów. Po pierwsze, ukrywający Żydów narażali całą zbiorowość na represje ze strony stosującego zasadę odpowiedzialności zbiorowej okupanta. A po drugie - ukrywanie Żydów często odbierano jako niczym nieuzasadnione, egoistyczne wzbogacanie się jednostek kosztem ogółu. 
Jak już zaznaczyliśmy powyżej, mord na Żydach w Rędzinach-Borku sam w sobie nie jest ani wydarzeniem niezwykłym, ani rzadkim. Mordy na ukrywających się Żydach zdarzały się bardzo często. Natomiast na uwagę zasługuje „wojskowy” charakter tej egzekucji, poprzedzająca ją mobilizacja oddziałów AK, rozkazy i planowanie, podział broni oraz koordynacja działań przynajmniej trzech jednostek operacyjnych. Najciekawsza w związku z tą kwestią jest kopia raportu sporządzonego przez Krzyszkiewicza i skierowanego do Komendanta Okręgu AK. Dokument ten, odnaleziony w domu Krzyszkiewicza podczas rewizji, jest na tyle istotny, że przytoczymy go w całości ${ }^{14}$. Jest to też dokument prawie współczesny opisywanym wydarzeniom:

„Do KO [Komendy Okręgu] Melduję posłusznie, że przeprowadzona przeze mnie akcja likwidacyjna żydów odbywała się w następujący sposób: w powyższej akcji brało udział 14stu członków organizacji. Po opanowaniu domu i wejściu do skrytki żydom polecono opuścić zajmowane przez nich miejsce i wyjść do sieni co też czterech z nich i jedna żydówka uczyniło. Jeden z nich nie usłuchał rozkazu i został z miejsca zastrzelony. Następnie Józef dokonał osobistej rewizji zabierając inne portfele $z$ pieniędzmi (jak się potem wypowiadał miało tam być 130 dolarów i około 10 tysięcy złotych), 3 zegarki i 3 pierścionki. Po dokonaniu tej rewizji osobistej, wszedłem sam do komórki celem przeprowadzenia rewizji w poszukiwaniu broni, która rzekomo miała się tam znajdować. Następnie przeszukałem znajdujące się tam części garderoby osobistej, z której wzięli ci co było im niezbędne, Antoni zabrał dwie pary trzewików, żółtych i kurtkę, Słowik wraz z dwoma swoimi ludźmi zabrał jeden plecak z bielizną i dwie jesionki. Ja dla siebie również zabrałem kurtkę. Pozostałych siedmiu nic nie zabrało ze sobą. Reszta towarów została na miejscu. Udając się celem zrealizowania podjętej akcji nie postępowaliśmy w myśl grabieży i osobistych zysków, lecz kierowaliśmy się ideą pozbycia się żydów, jako też zdobycia broni, którą rzekomo mieli posiadać, o czem może poświadczyć fakt, że siedmiu uczestników wyprawy nie odniosło żadnych korzyści. Co do mnie, to były pewne niedociągnięcia, które kładę na barki braku doświadczenia, gdyż nigdy nie liczyłem się z faktem, że będę posądzony, ja i moi ludzi, o grabież.

Po przeprowadzeniu rewizji i nieznalezieniu broni, żydów wprowadzono z powrotem do wnętrza i tam uszeregowanych twarzą do muru po kolei strzelano.

Po wykonaniu zadania poleciłem wszystkim obecnym zachowanie jak najdalej idącej tajemnicy, a gospodyni wydałem polecenie uprzątnięcia trupów nie robiąc żadnego rozgłosu.

Jeżeli chodzi o zdradzenie tajemnicy i sprowadzenie rozgłosu, to winę ponosi Józef z bojówki Dominika, który przy wódce w sklepie Strojowej [?] wbrew mej woli zwierzał się przed miejscowym chłopstwem z dokonanej operacji, a nawet gdy zwróciłem mu uwagę w delikatny sposób, że nie powinien przebywać w tym środowisku, rzucił się na mnie.

${ }^{14}$ APKr, SAKr, 1029/IVK/ 180/50, k. 10-10v. 
Co do mnie to wszystkie niedociągnięcia przyjmuję na własne barki, ale na usprawiedliwienie się chciałem powiedzieć, że nie liczyłem się z faktem posądzenia mnie o grabież pozwalając wyżej wymienionym zabrać ze sobą potrzebne im rzeczy, gdyż byli to ludzie, którzy przez wojnę stracili swój dobytek”.

Analiza tego dokumentu prowadzi do szeregu niepokojących wniosków. Przede wszystkim, nie ulega wątpliwości, że „akcja likwidacyjna” nastąpiła w wyniku rozkazu, wydanego przynajmniej na poziomie dowództwa Okręgu ${ }^{15}$. Uderza również całkowity brak refleksji nad celowością egzekucji, której celem, przynajmniej oficjalnie, miało być „pozbycie się uzbrojonych Żydów terroryzujących ludność”. Raport „Regińskiego”, będący w istocie próbą obrony własnych zdolności dowódczych, sprowadza się do naświetlenia dwóch zagadnień, które najwyraźniej wywołały krytykę przełożonych. Chodziło tu o kwestię grabieży własności pomordowanych oraz o brak dyscypliny wśród uczestników „akcji”. Dobra pożydowskie, według komendanta placówki „Kot” stanowiły zwykłe mienie zdobyte na nieprzyjacielu, a sam mord na Bogu ducha winnych ludziach, których jedyną winą było niewłaściwe pochodzenie, nie wzbudził w dowództwie Okręgu „Maria” żadnego zainteresowania. Nie stanął on też na drodze dalszej konspiracyjnej kariery „Regińskiego”, który pozostał komendantem placówki „Kot” aż do końca okupacji.

Czy można na podstawie tej „akcji likwidacyjnej” wyciągać dalej idące wnioski na temat miechowskiego AK i Żydów? Na tym etapie trudno na to pytanie odpowiedzieć, ale można dodać, że mord na Żydach w Borku nie był w kronice bojowej Placówki AK „Kot” czynem zupełnie wyjątkowym. Pewien czas potem ${ }^{16}$ pluton Krzyszkiewicza udał się na patrol „na obchud [pisownia oryginału - J. G.] terenu pod dowuctwem Cheblickiego ps. »Chubert« i w ten czas to udaliśmy się w stronę Kropidła [lub Dosłonki]. W ten czas musiał być meldunek do dowutcy placówki Chełbickiego ps. »Chubert«, że w Kropidle znajduje się Żyd którego trzeba zlikwidować. Po zejściu w środek wsi weszliśmy do nieznanego mi gospodarza, u którego znajdował przechowując się żyd. Gdy zbliżyliśmy się dorosły osobnik narodowości żydowskiej zaczął uciekać na widok nas uzbrojonych. Do którego oddał pierwszy strzał Gola Stanisław i Wesołowski Andrzej, po oddaniu kilku strzałów żyd upadł. Po czym go obrewidowano i kazano go gospodarzowi zakopać. Później udaliśmy się w dalszą patrol”. Niechętny, jeżeli tak można go nazwać, stosunek do Żydów nie był cechą szczególną tego właśnie plutonu. Wydaje się, że mord w Rędzinach-Borku nawet jeżeli chodzi o precyzję planowania - nie był zdarzeniem odosobnionym, gdyż do bardzo podobnej masakry ukrywających się Żydów doszło parę miesięcy później w pobliskiej Chruszczynie Wielkiej. We wsi tej, położonej ok. $20 \mathrm{~km}$ na wschód od miejsca omawianych wydarzeń, pięcioosobową rodzinę żydowską prze-

${ }^{15}$ Potwierdza to również wymiana korespondencji miechowskiego AK odnaleziona przez Dariusza Libionkę w zbiorze dokumentów miechowskiego AK. Dokumenty te zatrzymał UB po aresztowaniu Nieczui-Ostrowskiego, ostatniego komendanta Okręgu „Maria”. Zob. Archiwum Instytutu Pamięci Narodowej (AIPN), MBP, AK, 407.

${ }^{16}$ Przesłuchanie Krzyszkiewicza z dnia 26 I 1950 r. k. 144. 
chowywaną przez szereg miesięcy u miejscowego chłopa obrabował, a następnie rozstrzelał oddział Korpusu Bezpieczeństwa Batalionów Chłopskich. Sposób postępowania do złudzenia przypomina w tym wypadku akcję AK-owców z Kaliny Wielkiej ${ }^{17}$.

Lektura lokalnego pisma, wydawanego w podziemiu przez dowództwo miechowskiej AK, skłania do dalej idących refleksji. Wydaje się bowiem, że „zbandycenie” niektórych struktur Armii Krajowej w okręgu „Maria” (Miechów) nie uszło uwadze dowództwa okręgu Kraków. W grudniu 1944 r. wydawane podziemnie „Wiadomości do Komunikatów AK” zamieściły artykuł pt. Tępić chwasty! Warto przytoczyć fragment tego artykułu: „Tak, jak wśród wyborowego zboża wyrastaja chwasty, które zanieczyszczają ziarno, tak nawet i w najlepszym zbiorowisku ludzkim są jednostki zbrodnicze, będące jego zakałą. Nie uniknęła tego losu i nasza Armia Krajowa. Są tacy, którzy już wstępując w nasze szeregi mieli na celu wyrobienia sobie alibi na przyszłość, a co gorsza uważający swój pobyt w AK jako najlepszą sposobność do wyładowania swoich zbrodniczych instynktów, swojej żądzy krwi i rabunku"18.

\section{Zakończenie}

W 1949 r. na skutek „poufnego doniesienia” milicja w Miechowie wpadła na trop morderstwa. Wizyta w domu Szycha potwierdziła treść donosu, rewizja w domu Krzyszkiewicza zaowocowała odkryciem cytowanego powyżej raportu, a zapadnięte klepisko w stodole pozwoliło szybko zidentyfikować miejsce pochówku zamordowanych Żydów. Ekshumowano wówczas szczątki kilku osób ${ }^{19}$. Dające się wyodrębnić szkielety i czaszki załadowano do dwóch trumien i pogrzebano na pobliskim cmentarzu. Pozostałe szczątki, niemożliwe do zidentyfikowania, polecono zasypać w stodole, w tej samej jamie, w której spoczywały od tragicznego listopada $1943 \mathrm{r}$.

Główny oskarżony, Bolesław Krzyszkiewicz ps. „Regiński”, w sądzie pierwszej instancji dostał wyrok śmierci. W 1951 r. wyrok ten decyzją Prezydenta RP Bolesława Bieruta został zamieniony na dożywocie. Dowódca Placówki AK Kalina Wielka wyszedł ostatecznie na wolność w 1965 r. Trzeba przyznać, że jeżeli chodzi o długość „odsiadki” za mordowanie Żydów, to Krzyszkiewicz w więzieniu siedział wyjątkowo długo. Mordercy Żydów w ogromnej większości wypadków (w tym wszyscy współoskarżeni „Regińskiego”) wychodzili na wolność już w latach 1955-1957.

17 AIPN, GK 306, teczka 32, Sąd Wojewódzki w Kielcach. Jestem zobowiązany Alinie Skibińskiej za zwrócenie mi uwagi na tę sprawę.

${ }^{18}$ „Wiadomości do Komunikatów AK”, nr 5, Maria (Miechów), 17 XII 1944. Pismo to można znaleźć m.in. w kolekcji „Prasa konspiracyjna”, Biblioteki Narodowej w Warszawie. Z podobnym apelem do żołnierzy AK wystąpił 29 listopada 1944 r. Komendant Okręgu Kraków. Zob. Archiwum Akt Nowych (AAN), zespół Armia Krajowa (AK), 203\XI-43, [Mf 2396/3], k. 36 .

${ }^{19}$ Zob. załączony poniżej protokół z ekshumacji. 
W trzydzieści lat później, już w wolnej Polsce, Krzyszkiewicz wystąpił do sądu w Krakowie o rehabilitację - jako ofiara komunistycznych prześladowań. „Regiński” nie wypierał się co prawda samego mordu, lecz tłumaczył się rozkazami płynącymi z góry. Sąd oddalił jednak jego roszczenia, argumentując, że zaskarżany wyrok nie dotyczył działalności patriotycznej, lecz mordowania Żydów: „Nie kwestionując działalności Bolesława Krzyszkiewicza w AK należy stwierdzić”, pisali sędziowie w uzasadnieniu, „że czyny mu przypisane nie były związane i w żadnym razie nie służyły sprawie niepodległego bytu Państwa Polskiego”20. Nieco innego zdania na temat całokształtu wojennej działalności Krzyszkiewicza było jednak Wojsko Polskie, gdyż, jak doniosła „Gazeta Miechowska” (nr 103), w dniu 11 lipca 2003 w siedzibie Stowarzyszenia Żołnierzy AK w Miechowie miało miejsce miłe spotkanie, podczas którego „przedstawiciel wojskowej komendy uzupełnień Kraków - Nowa Huta wręczył Bolesławowi Krzyszkiewiczowi nominację na stopień majora, a kilkanaście innych osób z gmin: Miechów i Książ Wielki otrzymało nominację na I stopień oficerski [...]. Odznaczonym gratulowali koledzy, m.in. prezes honorowy SŻAK koło w Miechowie Stefan Kwiecień, a także Stanisław Piwowarski - kustosz Muzeum Historycznego Miasta Krakowa”21. Nie był to jednak koniec wojskowej kariery Krzyszkiewicza „Regińskiego”, który w dwa lata później, 1 czerwca 2005 r., dostał kolejny awans - tym razem na stopień podpułkownika Wojska Polskiego.

Dziś w Rędzinach-Borku nie mieszka już nikt z rodziny Szychów. Nie zachował się też żaden ślad po stodole kryjącej szczątki ofiar mordu. A w Borku i w Kalinie Wielkiej (gdzie mieści się najbliższy cmentarz) nie ma już śladu po mogile ekshumowanych Żydów.

\section{DOKUMENTY}

Nr 1

APKr, SAKr 1029-IV K 180/50 k. 24.

Protokół

Z przeprowadzonej ekshumacji zwłok w gromadzie Rędziny Borek gm. Racławice u Szych Franciszka w dniu 8 marca 1950 roku, zarządzonej na polecenie Prokuratora Apelacyjnego ob. Brandysa.

${ }^{20}$ Nieco wcześniej, w 1992 r., Sąd Wojewódzki w Krakowie w podobny sposób i z tym samym uzasadnieniem odrzucił prośbę Andrzeja W. ps. „Słowik”, który w 1950 r. dostał wyrok 10 lat więzienia. W. wyszedł na wolność w 1956 r. a w trzydzieści sześć lat później starał się bezskutecznie - o zaliczenie lat spędzonych w więzieniu do emerytury.

${ }^{21}$ Jestem wdzięczny Dariuszowi Libionce za zwrócenie mi uwagi na tę notę. 
Obecni:

1. Podprokurator Sądu Okręgowego: Julian Findysz

2. Lekarz powiatowy: Dr. Rymarowicz Antoni

3. Przedstawiciel PUBP: ppor. Kubański

4. Komendant posterunku MO Racławice: ob. Makuszewski Mieczysław

5. Sołtys gromady Rędziny-Borek: Klimczyk Stanisław

W stodole u ob. Szycha Franciszka na głębokości 3 m. w dole o wymiarach 150 x 150 cm w miejscu widocznym, odróżniającym się od reszty klepiska zapadnięciem stwierdzono szkielet człowieka o wymiarach $170 \mathrm{~cm}$. Czaszka szkieletu nie uszkodzona. Szkielet gdzieniegdzie po stronie grzbietowej miał zachowane resztki tkanki mięsnej. Szkielet wskazywał wyraźnie, że był to mężczyzna średniego wzrostu. Z oględzin czaszki wynika, że mężczyzna miał czaszkę prawidłowo zbudowaną, symetryczną bez śladów uwłosienia, ponadto w szczęce górnej stwierdzono 10 zębów. Szczęka dolna miała utrzymanych 12 zębów. Po wyjęciu czaszki z ziemi, poszczególne zęby zaczęły wylatywać. Stwierdzono, że 10 zębów w szczękach było złotych, które protokolarnie, jako dowód rzeczowy przekazano do PUBP w Miechowie. Bezpośrednio pod szkieletem pierwszym stwierdzono szkielet kostny pozbawiony tkanki miękkiej, czaszka średniej wielkości, symetryczna, kość czołowa niska, jedynie częściowo pokryta zwiotczałą tkanką mięsną. Czaszka nieuszkodzona, dość duże braki w uzębieniu, uzębienie częściowo sztuczne, mostek z białego metalu, prawdopodobnie złotego, który jako dowód rzeczowy przekazano do PUBP w Miechowie. Pod szkieletem kostnym stwierdzono część tułowia, a więc: klatka piersiowa, jama brzuszna i kończyny górne jak gdyby przyklejone do jamy brzusznej, tak że lewa dłoń przykrywa widoczne uwłosienie nad kością łonową. Całość była mocno zawilgocona i tworzyła jednolitą masę podatną na ucisk. Cała ta masa wydzielała niemiłą, gnilną woń. Przy czaszce znaleziono kępki włosów koloru słomianego. Pod tym szkieletem stwierdzono masę bezkształtną, mocno zawilgoconą, wydającą nieprzyjemną woń. Równocześnie stwierdzono dalszą czaszkę bez owłosienia, posiadającą w okolicy kości skroniowej i potylicznej otwór o średnicy $1 \mathrm{~cm}$, nierówny. Jak wynika z brzegów otworu, otwór ten wskazuje na wylot pocisku. Obok tej czaszki znaleziono jeszcze dwie czaszki, z których jedna miała zachowane włosy długie, siwawe, wskazujące na to, że są to włosy kobiece. W czaszce tej stwierdzono otwór w szczęce górnej, wskazujący na to, że był to wlot kuli. Po dokładnych oględzinach nie stwierdzono wylotu. W czaszce tej stwierdzono jeszcze tkankę mózgową koloru popielatego, w stanie półpłynnym. W ostatniej czaszce stwierdzono brak częściowy szczęki górnej i ubytek kostny w tyle czaszki o brzegach nierównych. Ze względu na to, że masa była zupełnie bezkształtna i nie dawała możliwości rozpoznania różnych części, postanowiono nie wyjmować jej z ziemi. Pozostałe zaś czaszki i szkielet wydobyte z ziemi złożono do trumny z czego pierwszy szkielet polecono umieścić w osobnej trumnie. Szkielety pochowano na cmentarzu w gr. Rędziny Borek. 
Protokół przesłuchania podejrzanego

Miechów, 28 grudnia 1949 r. Kubański Jan, oficer śledczy w Pow. Urzędzie Bezpieczeństwa Publicznego w Miechowie przesłuchał w charakterze podejrzanego

Nazwisko i imię: Krzyszkiewicz Bolesław ps. „Regiński”

Odznaczenia i ordery: Brązowy Krzyż Zasługi z AK

Przynależność partyjna: PZPR

Co do organizacji wyjaśniam: w grudniu 1939 roku przyszedł do mnie Szarek Teofil zam. w Kalinie Małej i podczas rozmowy zaproponował mi by wstąpić do konspiracji w organizacji ZWZ na co się zgodziłem. Równocześnie w tym samym dniu do organizacji ZWZ wstąpił Wojtas Franciszek, Regnicki Józef i Tondos Julian zam. w Kalinie Małej gm. Wielkie Zagórze, pow. Miechów. Po utworzeniu nowej organizacji Teofil Szarek był jako dowódca ZWZ. Pierwszym zadaniem ZWZ było rozsiewanie propagandy i podtrzymywanie ludności na duchu. W 1941 roku do mnie przybył major „Paweł” i Darek, który był maszynistą w Rybniku, lub w Pszczynie. Równocześnie grupa nasza przystapiła do organizacji „Konfederacja Zbrojna”, której komendantem był major „Paweł”22 na terenie Miechowa i okolicy. Po przyłączeniu się do „Konferederacji Zbrojnej” masowo werbowaliśmy członków, praca zaś polegała w celu siania propagandy. W roku 1943 ZWZ zostało połączone z „Konfederacją Zbrojną” w organizację AK. Po połączeniu major „Paweł” zostaje odwołany ze swego stanowiska, a na jego miejsce zostaje powołany ps. „Janusz” ${ }^{23}$, jako komendant obwodu AK na teren miechowski. W tym samym czasie zostaje organizacja AK przeorganizowana na oddziały terenowe: kompanie, bataljony, pułki i dywizje. Na czele 1 kompanii byłem ja, tj. Bolesław Krzyszkiewicz ps. „Regiński”, która obejmowała teren Kalina Mała i Wielka, Rędziny, Brzuchanie, Strzeżów I-szy i II-gi, Siedliska. Na czele kompanii II-giej był dowódca Trapiołek, ps. „Mnich” zam. w Ilkowicach gm. Słaboszów, który obejmował teren Słaboszowa. Dowódca III-ciej kompanii był ps. „Cedro” nazwisko Bożek, zam. w Książu Wielkim pow. Miechów, który obejmował teren gm. Książ Wielki. Te trzy kompanie wchodziły w skład 1-go batalionu, którego dowódcą początkowo był Malinowski, kierownik szkoły z Książa Wielkiego ps. „Słowik”, który był dowódcą batalionu do 1944 roku $^{24}$. Z wiosną 1944 r. dowództwo objął Sikorski ps. „Kara” zam. w Miechowie.

${ }^{22}$ Paweł Włoczek, ps. „Paweł”, organizator i komendant Konfederacji Zbrojnej, II zastępca komendanta Obwodu Miechów.

${ }^{23}$ Pomyłka, komendantem obwodu miechowskiego został nie „Janusz”, lecz Jerzy Jasielski ps. „Jawa”. Zob. J. Guzik, Racławickie Wezwania. Monografia okupacyjna ziemi miechowskiej, 1939-1945, Wawrzeńczyce 1987, s. 225.

${ }^{24}$ Ppor. rez./kapitan Julian Malinowski „Słowik”, komendant Podobwodu Książ Wielki, „Kazia” . 
Prócz tego był II-gi batalion, na czele którego stał ps. „Fałat” nazwiska nie znam. Te dwa bataliony I-szy i II-gi nosiły nazwy wschodni i zachodni. Na czele wschodniego batalionu był Sikorski ps. „Kara”, a zachodniego był ps. „Fałat”25. Bataliony te wchodziły w skład pułku, na czele którego stał kapitan ps. „Mak”26, który był bezpośrednio podległy dowódcy dywizji jakim był Ostrowski ps. „Tysiąc”27. W roku 1943 została utworzona przez dowódcę dywizji grupa Dywersyjna, na czele której był ps. „Żbik”28. Grup dywersyjnych było rozrzuconych dużo po terenie, dopiero w roku 1944 połączono te grupy w I-y pluton leśny pod nazwą „Skrzetuski”, na czele którego stał „Żbik”. W tym samym czasie z oddziałów terenowych zostaje wyłoniony pluton żandarmerii, na którego czele stoi Antoni Bac ps. „Lutek” zam. w Strzeżowie gm. Wielkie Zagórze pow. Miechów. W plutonie żandarmerii z mojego terenu był Stanisław Włodarczyk zam. w Kalinie Małej. Grupa żandarmerii miała na celu utrzymać porządek oraz wykonywać egzekucje na zlecenie dowództwa.

Dowództwo dywizji posiadało pluton łączności i radiostację, którą posiadał Danecki zam. w Miechowie

Pytanie: Opowiedzcie zajście jakie mieliście z obywatelami narodowości żydowskiej?

Odp. W miesiącu październiku 1943 r. daty dokładnie nie pamiętam przyszedł do mnie Antoni B., dowódca plutonu żandarmerii i oznajmił, że na terenie mojej placówki znajduje się grupa żydów u Szycha, zam. Rędziny Borek gm. Racławice pow. Miechów i chciał bym ich sam zlikwidował. W tej sprawie po otrzymaniu takich wiadomości udałem się osobiście do komendanta obwodu ps. „Janusz”, któremu opowiedziałem, że na moim terenie znajduje się grupa żydów i co z nimi zrobić. Dowódca „Janusz” polecił mi by żydów tych zlikwidować. Po otrzymaniu tych informacji porozumiałem się z dowódcą grupy Dywersyjnej „Żbika” oraz zarządziłem by dał mi ludzi w celu likwidacji tych żydów, gdzie otrzymałem 5-ciu uzbrojonych członków Grupy Dywersyjnej „Żbika”. Prócz tego porozumiałem się z Stanisławem Ch. zam. w Giebułtowie gm. Książ Wielki pow. Miechów by on również dał mi ludzi w celu likwidacji tych żydów, na co wyraził zgodę przychodząc sam i trzech innych nieznanych mi, również uzbrojonych. W kilka dni później wszyscy członkowie od „Żbika” i Ch. przybyli na umówione miejsce obok lasu w Kalinie, jak również i ja wraz ze swymi członkami tj. Teofilem Sz. zam. w Kalinie Małej, Mieczysławem L. zam. w Kalinie Małej gm. Racławice udaliśmy się na wyznaczone przeze mnie miej-

${ }^{25}$ Por. rez. Julian Stanik ps. „Fałat”, pierwszy komendant Obwodu Miechów, „Mech-Magdalena".

${ }^{26}$ Kpt. Emil Gutowski, ps. „Mak”.

${ }^{27}$ Bolesław Michał Nieczuja-Ostrowski, od 1 IX 1943 r. dowódca Inspektoratu Miechów AK oraz 106 Dywizji AK.

${ }^{28}$ Ppor. rez. Stanisław Jazdowski. „Żbik” zginął w walkach z Niemcami w sierpniu 1944 r. Zob. B.M. Nieczuja-Ostrowski, op. cit., s. 413-416. 
sce. Po przybyciu na miejsce zaczekałem pod lasem na ludzi, którzy mieli przyjść, a gdy przyszli oznajmiłem im jaki jest nasz cel, że będziemy strzelać żydów, którzy są w domu u Szycha. O godz. 22-giej w nocy byliśmy pod domem, który został obstawiony przez moich ludzi pozostających do mojej dyspozycji jako komendanta plutonu egzekucyjnego. Z chwilą gdy zapukaliśmy do domu nikt się nie odzywał, wobec czego drzwi zostały wyrwane i weszliśmy do mieszkania, następnie zastaliśmy kobietę, której zapytali się członkowie „Żbika” gdzie znajdują się żydzi. Następnie kobieta ta wskazała nam palcem na drzwi. Ja osobiście nie pytałem się, ponieważ obawiałem się by mnie nie poznała. Po wejściu do mieszkania wskazanego zastałem 4-ch żydów i jedną żydówkę, którzy siedzieli w pokoju sami. W pierwszym rzędzie żydzi i żydówka zostali zrewidowani i poodbierano im wszystko, następnie zostali ustawieni pod ścianę i z tyłu zostali rozstrzelani w tymże mieszkaniu. Po zastrzeleniu żydów i żydówki dałem polecenie kobiecie tej by ich z mieszkania usunęła i zakopała. Co zrobiła z tymi pięcioma trupami tego nie wiem i nie jest mi wiadomo gdzie ich zakopała, natomiast my ich nie chowali.

Zaznaczam, że żydom tym zostały odebrane wszystkie rzeczy jakie posiadali tj. ubrania, płaszcze, sygnety i inne rzeczy, a dopiero po rewizji zostali rozstrzelani. Po dokonanej egzekucji na 4-ch żydach i żydówce zawiadomiłem o tym komendanta obwodu ps. „Janusz”, że żydzi ci zostali rozstrzelani. Jaką broń posiadał Mieczysław L. i Teofil Sz. którzy brali udział w egzekucji, nie mogę sobie przypomnieć.

\section{Nr 3}

APKr, SAKr 1029-IV K 180/50 k. 39-40

Protokół przesłuchania Andrzeja W., 14 lutego 1950 r.

Przez cały czas okupacji nie pracowałem nigdzie, utrzymywałem się tylko z drobnego handlu aż do wyzwolenia Polski spod okupacji niemieckiej. Do organizacji podziemnej Konfederacji Zbrojnej wstąpiłem w kwietniu 1940 roku. Przysięgę na wierność organizacji składałem mjr „Pawłowi” otrzymując ps. „Słowik”. Konfederacja Zbrojna została włączona do ZWZ i powstała Armia Krajowa. Będąc w AK moim dowódcą został mianowany Bolesław Krzyszkiewicz psd. „Regiński”, który był podległy dowódcy Okręgu. Będąc u „Regińskiego” w roku 1943 zostałem przez „Regińskiego” mianowany na komendanta placówki Kaliny Wysiołek i Zarzecze. Jako komendant placówki posiadałem pod sobą 10 ludzi.

Pyt.: Kiedy i z kim braliście udział w strzelaniu ob. narodowości żydowskiej?

Odp.: Było to w zimie 1943 r. daty dokładnie nie pamiętam, otrzymałem polecenie od Krzyszkiewicza ps. „Regiński” by stawić się u niego wraz ze swoją grupa ludzi. Rozkaz wykonałem i tego samego dnia wieczorem ja wraz z K., Ż., G. M. zeszliśmy do Kaliny Małej do domu Krzyszkiewicza, zostaliśmy uzbrojeni w broń, następnie zastałem u niego czekających innych członków również uzbrojonych. 
Gdy wszystko zostało uszykowane, Krzyszkiewicz poprowadził nas marszem ubezpieczonym do miejscowości Kalina Rędziny, do jednego gospodarza, który mieszkał pod lasem. Będąc pod lasem Krzyszkiewicz ps. „Regiński” oświadczył nam, że w domu tym znajdują się żydzi, następnie kazał nam otoczyć dom, on zaś z innymi udał się do mieszkania w celu stwierdzenia czy żydzi rzeczywiście się tam znajdują. Żydzi ci, których było około pięciu zostali w mieszkaniu zastrzeleni ponieważ w mieszkaniu było słychać pojedyńcze strzały. Gdy wyszedł Krzyszkiewicz z tego domu od Szycha, polecił by wszyscy się rozeszli do domu, broń zaś w którą byli uzbrojeni moi ludzi zdali grupie Krzyszkiewicza. Wiadomym mi jest, że rzeczy tych żydów jak zegarki, pierścionki zostały im zabrane.

Prócz w/w w likwidacji tych żydów brał udział Mieczysław L. i wielu innych których nazwisk nie pamiętam. Nadmieniam przy tym, że jest mi wiadomym od ludzi z Kaliny Małej, że Szych zdradził tych żydów i domagał się by ich zlikwidować, ponieważ obawiał się żeby Niemcy go nie zastrzelili oraz jego rodziny. W sprawie tej dokładnie winien wiedzieć Krzyszkiewicz Bolesław ps. Regiński, albo Mieczysław L. Następnie w roku 1944 daty dokładnie nie pamiętam w porze letniej, ja wraz ze swymi członkami tj. Stanisławem G. zam. Kalina Wysiołek, Władysławem M. zam. Kalina Wysiołek, A., Mieczysław L., Krzyszkiewicz Bolesław i inni członkowie grupy z Kaliny Wielkiej, których nazwiska może dokładnie zapodać A. Prócz tego byli członkowie z grupy Huberta i sam Hubert. W/w członkowie z grupy 106 Dywizji Tysiąca pod dowództwem Huberta por. odbywali w tym czasie patrol, ogólna suma wszystkich ludzi wynosiła około 40 osób. Podczas patroli nocnej w miejscowości Dosłonce, pow. Miechów u jednego gospodarza napotkaliśmy w stodole obywatela narodowości żydowskiej, który został zastrzelony w stodole, kto go strzelał, tego nie wiem dokładnie. Po zastrzeleniu tego żyda dowództwo poleciło żyda tego pochować. Ja osobiście do żyda nie strzelałem.

\section{$\mathrm{Nr} 4$}

APKr, SAKr 1029-IV K 180/50 k. 71-72

Protokół przesłuchania Bolesława Ż. ps. „Sęp”, 2 maja 1950 r.

Było to w zimie 1943 roku, daty dokładnie nie pamiętam, przyszedł do mnie członek AK Marian G. zam. w Kalinie Wielkiej, gmina Racławice, który powiadomił mnie, że mam się zgłosić na zbiórkę w umówionym miejscu, tj. w lasku obok Kaliny Wielkiej. Po otrzymaniu takowej wiadomości udałem się razem z nim pod wieczór na wyznaczone miejsce. W lesie tym gdy zaszliśmy, zastałem Andrzeja W. ps. „Słowik” i nieżyjącego Kazimierza J. skąd razem udaliśmy się do Kaliny Małej, do dowódcy kompanii ps. „Regiński”. W domu u Regińskiego zastaliśmy kilku ludzi nieznanych mi, częściowo uzbrojonych. Gdy wszyscy przyszli, dowódca kompanii „Regiński” poprowadził nas przez pola pod dom, który znajdował się około lasu w Rędziny Borek, do nieznanego mi gospodarza. Będąc pod domem „Regiński” za- 
trzymał całą grupę i oświadczył, że w tym budynku znajdują się żydzi oraz wydał polecenie by go ubezpieczyć. Gdy dom został ubezpieczony dwóch nieznanych mi członków wybiło okna do mieszkania, następnie otworzyli drzwi od sieni, do której wszedł „Regiński” zabierając ze sobą mnie i Andrzeja W. ps. „Słowik”. W tym to czasie dwóch nieznanych mi osobników otworzyło drzwi do komory, w której znajdował się jeden żyd, reszta zaś była ukryta. W drzwiach stanąłem ja i „Regiński”, który wydał rozkaz żydowi by podniósł ręce do góry, a gdy ten nie chciał tego uczynić, „Regiński” wydał mi polecenie żeby strzelać, ja wówczas dałem strzał ostrzegawczy, a gdy nie podniósł rąk do góry, dałem drugi strzał w kolano i żyd ten został zastrzelony, reszta żydów i jedna żydóweczka wyszli z kryjówki. Dwaj nieznani mi całkiem członkowie AK wyprowadzili tych żydów do sieni i przeprowadzili rewizję, podczas której zostały im zabrane portwele, zegarki, obrączki i pierścionki, rzeczy te zabrali ci właśnie dwaj nieznani mi całkiem osobnicy. Gdy zostali zrewidowani z sieni zostali wyprowadzeni z powrotem do komory i ustawieni twarzą do ściany. Wówczas „Regiński” z pistoletem stanął pierwszy obok dwóch nieznanych mi osobników, ja byłem czwarty, a W. piąty, a my byliśmy z karabinami, ci dwaj zaś nieznani mi osobnicy byli z pistoletami. Gdy wszystko było gotowe, żydzi ci prosili się i mówili w te słowy: „darujcie nam życie” lecz pomimo to „Regiński” dał pierwszy strzał w tył żydowi, a następnie wszyscy z kolei strzelaliśmy z tył w głowy. Po wykonaniu wyroku śmierci na tych żydach udałem się wraz z Andrzejem W. i J. oraz z Marianem G. do domu.

Chcę przy tym nadmienić, że nie byłem uświadomiony co czyniłem gdyż dowódca, jakim był „Regiński” dał polecenie i wykonywałem [je] tylko jako żołnierz Armii Krajowej.

\section{Nr 5}

SENTENCJA WYROKU.

W Imieniu Rzeczypospolitej Polskiej.

Dnia 24 października 1950 r.

Sąd Apelacyjny w Krakowie, Wydział III Karny w składzie następującym:

Przewodniczący S. S.: A.B. Kobylarz

Ławnicy: $\quad$ 1/ Franciszek Garło

2/ Witold Kielar

Protokolant: apl. K. Kępiński

w obecności oskarżyciela publicznego: Prokuratora Wojewódzkiego Z. Jasińskiego rozpoznawszy dnia 23-24 października 1950 r. sprawę:

1/ Bolesława Kr z y s z k i e w i c za ps. „Regiński” [...] pochodzenia społ. robotniczego, urzędnika P.D.T. w Chorzowie, wykształcenia średniego, bez majątku, żonatego, 1 dziecko, członka PZPR, karanego przez Rej. Sąd Wojsk. w Krakowie za posiadanie broni na lat 10 więzienia, aresztowanego od 16 XII 1949 r., obywatelstwa polskiego, 
2/ Andrzeja W. ps. „Słowik”, [...] pochodzenia chłopskiego, kancelistę, obywatelstwa polskiego, wykształcenie $7 \mathrm{kl}$. szkoły pow., żonatego, bezdzietnego, bez majątku, pracownika dyrekcji PKP w Szczecinie, członka PZPR, nie karanego, aresztowanego dnia 10 II 1950 r.,

3/ Bolesława Ż. ps. „Sęp”, obywatelstwa polskiego, pochodzenia społ. robotniczego, strażnika SOK PKP, wykształcenia 6 kl. szkoły pow., żonatego, 2 dzieci, bez majątku, nie karanego, bezpartyjnego, aresztowanego dnia 22 II $1950 \mathrm{r}$.

4/ Mieczysława L. ps. „Sęp”, syna policjanta granatowego, pracownika umysłowego, wykształcenia średniego, żonatego, 3 dzieci, bez majątku, rzekomo nie karanego, członka PZPR. [...]

5/ Ignacego K., ps. „Wels” [...] pochodzenia społ. chłopskiego, przynależności robotniczej, wykształcenia $3 \mathrm{kl}$. szk. pow., urzędnika, kawalera, bez majątku, rzekomo nie karanego, członka PZPR, aresztowanego 16 I 1950 r. plutonowego rezerwy R.K.U. Miechów,

6/ Mariana G. ps. „Wieczorek” [...], obywatelstwa polskiego, pochodzenia społ. robotniczego, z zawodu młynarza, zajęcia elektromotera, wykształcenia $7 \mathrm{kl}$. szk. pow., kawalera, bez majątku, rzekomo nie karanego, członka PZPR, aresztowanego 26 II 1950 r. [...]

7/ Tomasza M. ps. „Rzeka” obywatelstwa polskiego, pochodzenia społ. chłopskiego i przynależności społ. chłopskiej, rolnika, wykształcenia $7 \mathrm{kl}$. szk. powsz., żonatego, 1 dziecko, bez majątku, rzekomo nie karanego, bezpartyjnego, aresztowanego od 18 II 1950 r., strzelca rezerwy, RKU Miechów

oskarżonych:

o to, że:

I. w listopadzie 1943 r. w Rędzinach-Borku gm. Racławice pow. Miechów, idąc na rękę władzy państwa niemieckiego jako członkowie AK /Armii Krajowej/ 106 Dywizji „Tysiąca” pod dowództwem Bolesława Krzyszkiewicza ps. „Regiński” brali czynny udział w zastrzeleniu 6-ciu żydów, którzy ukrywali się w domu Franciszka Szycha, a ponadto

1/ Bolesława Krzyszkiewicza ps. „Regiński” s. Jakuba

2/ Andrzeja W. ps. „Słowik”

3/ Mieczysława L. ps. „Sęp”

4/ Stanisława G. ps. „Błędowski” [...] obywatelstwa polskiego, pochodzenia chłopskiego, rolnika, posiadającego 4 ha ziemi, i zabudowania, wykształcenie $7 \mathrm{kl}$. szkoły powszechnej, rzekomo nie karanego, bezpartyjnego, aresztowanego w dniu 6 II 1950 r., kaprala rezerwy, RKU Kraków

oskarżonych:

o to, że:

II. w 1944 r. w Dosławicach pow. Miechów idąc na rękę władzy państwa niemieckiego jako członkowie AK /Armii Krajowej/ 106 Dywizji „Tysiąca” działając 
wspólnie z innymi nieustalonym sprawcami, wzięli czynny udział w zastrzeleniu 1-go żyda,

to jest o czyny, wskazane pod pkt. I. i II. przewidziane w art. 1 ust. 1 Dekretu z dnia 31 VIII 1944 r. Dz.U.R.P. Nr 69, poz. 377.

I. Krzyszkiewicza Bolesława, ps. „Regiński”, Andrzeja W. ps. „Słowik”, Bolesława Z. ps. „Sęp”, Mieczysława L., ps. „Sęp”, Ignacego K. ps. „Wels” i Mariana G. ps. „Wieczorek” u z n a j e za winnych czynu zarzucanego im w ustępie I. aktu oskarżenia, czym dopuścili się zbrodni z art. 1 ust. 1 Dekr. z dnia 31 VIII 1944 r. Dz.U.R.P. Nr 69 poz. 377/46 i za czyn ten na zasadzie art. 1 ust. i art. 7 cytowanego dekretu skazuje:

1/ Krzyszkiewicza Bolesława ps. „Regiński”,

2/ Andrzeja W. ps. „Słowik” i

3/ Bolesława Ż. ps. „Sęp” na karę śmierci oraz utratę praw publicznych i obywatelskich praw honorowych na zawsze i przepadek całego mienia każdego z oskarżonych.

Uznając, że oskarżeni Mieczysław L. ps. „Sęp”, Ignacy K. ps. „Wels” i Marian G. ps. „Wieczorek” czynu powyższego dopuścili się z rozkazu swoich władz przełożonych za czyn powyższy na zasadzie art. 1 ust. 1 i art. 7 przy zastosowaniu art. $5 \S 1$ i 2 cytowanego dekretu skazuje każdego z nich na karę więzienia po 6 /sześć/ lat oraz utratę praw publicznych i obywatelskich praw honorowych na czas po 2 /dwa/ lata i przepadek mienia każdego z nich.

II. Krzyszkiewicza Bolesława ps. „Regiński” uznaje za winnego czynu zarzucanego mu w ustępie II. aktu oskarżenia, czym dopuścił się zbrodni z art. 1 ust. 1 dekretu z dnia 31 VIII 1944 r. i za czyn powyższy na zasadzie art. 1 ust. 1 i art. 7 tegoż dekretu skazuje go na karę śmierci oraz utratę praw publicznych i obywatelskich praw honorowych na zawsze i przepadek całego mienia oskarżonego.

III. Na zasadzie art. 31 i 34 K.K. wymierza oskarżonemu Bolesławowi Krzyszkiewiczowi ps. „Regiński” łączną karę śmierci oraz łącznie utratę praw publicznych i obywatelskich praw honorowych na zawsze i łącznie przepadek całego mienia oskarżonego.

IV. Oskarżonych Andrzeja W. ps. „Słowik”, Mieczysława L. ps. „Sęp” uniewinnia z zarzutu objętego ust. II aktu oskarżenia, a oskarżonych Tomasza M. ps. „Rzeka” i Stanisława G. ps. „Błędowski” uniewinnia w zupełności z zarzutów oskarżenia, a kosztami postępowania z tym związanymi obciąża Skarb Państwa.

IV. zwalnia oskarżonych Krzyszkiewicza Bolesława ps. „Regiński”, Andrzeja W. ps. „Słowik”, Bolesława Z. ps. „Sęp”, Mieczysława L. ps. „Sęp”, Ignacego K. ps. „Wels” i Mariana G. ps. „Wieczorek” od obowiązku uiszczenia opłaty sądowej i ponoszenia kosztów postępowania związanych ze skazaniem, którymi obciąża Skarb Państwa.

V. Zalicza oskarżonym 1/ Mieczysławowi L. ps. „Sęp” na poczet orzeczonej kary okres tymczasowego aresztowania od dnia 3 I 1950 r. do dnia 24 X 1950 r., 2/ Ignacemu K. ps. „Wels” od dnia 16 I 1950 r. do dnia 24 X 1950 r. i 3/ Marianowi G. ps. „Wieczorek” od dnia 26 II 1950 r. do dnia 24 X 1950 r. 


\section{UZASADNIENIE}

Wszyscy oskarżeni w początkach okupacji uświadomili sobie konieczność walki z okupantem i podążyli tam, gdzie wyobrażali sobie i gdzie głoszono, że konieczność chwili wymaga tej walki. Poprzez ZWZ a następnie Konfederację Zbrojną i w końcu AK liczyli oni, że spełnią swój żołnierski obowiązek. Zgubna polityka kierownictwa AK z upływem czasu zawiodła szerokie rzesze niewątpliwie patriotycznie nastawionych żołnierzy, postawiła ich w stan stania z bronią u nogi co w rezultacie niejednokrotnie zupełnie wypaczyło nastawienie szeregowych i pchnęło ich niejednokrotnie do zbrodni i do działalności, która szła po linii okupacyjnej polityki niemieckiej.

Oskarżeni mieszkając i działając na terenie powiatu miechowskiego wchodzili w skład 106 dywizji „Tysiąca” przyczym osk. Bolesław Krzyszkiewicz był dowódcą kompanii, a Andrzej W. był dowódcą plutonu w skład którego wchodził Bolesław Z., Mieczysław L. i inni, z wyjątkiem Ignacego K., który wchodził w skład plutonu „Rolanda”.

W toku rozprawy głównej po wysłuchaniu wyjaśnień oskarżonych i zeznań świadków ustalone zostało, że w listopadzie 1943 r. zgłosił się do osk. Krzyszkiewicza Bolesława dowódca oddziału żandarmerii Antoni B. i oznajmił mu, że na terenie Rędziny Borek w domu Franciszka Szycha ukrywa się grupa żydów, która dokonuje rozbojów z bronią w ręku, która jest więc niebezpieczna dla ludności i niepożądana w terenie i którą wobec tego należy zlikwidować.

Oskarżony Krzyszkiewicz Bolesław podjął się tego zadania i nie analizując bliżej na tle sytuacji wytworzonej przez wojnę zasadności takiego twierdzenia, wydał swym podwładnym rozkaz zbiórki z bronią w ręku, i jako miejsce zbiórki wyznaczył swój dom w Kalinie Małej. W oznaczonym dniu i porze stawili się członkowie A.K. wezwani przez swych dowódców przyczym stawili się wszyscy oskarżeni z wyjątkiem osk. Tomasza M. albowiem nikt w przewodzie sądowym nie stwierdził i nie zauważył jego obecności w tej akcji z wyjątkiem osk. Andrzeja W., który tego rodzaju zeznanie złożone w śledztwie na rozprawie odwołał stwierdzając, że wobec innych stanowczych wyjaśnień w tej kwestii - widocznie się pomylił, oraz z wyjątkiem osk. Stanisława G., który do akcji tej nie był wezwany, oraz stawili się inni członkowie z sąsiedniej grupy „Żbika”.

Na miejscu zbiórki oskarżony Krzyszkiewicz Bolesław dokonał odprawy jeśli nie $\mathrm{z}$ całością to $\mathrm{w}$ każdym razie $\mathrm{z}$ dowódcami plutonów i poinformował ich o celu wyprawy.

Następnie cała grupa udała się do Rędzin Borku i po przybyciu na miejsce w pobliżu domu Szycha, osk. Krzyszkiewicz ponownie zapowiedział cel przybycia, poczym porozdzielał zadania i wyznaczył ubezpieczenie. Sam razem z Bolesławem Ż. z dwoma członkami ze „Żbika” postanowił przeprowadzić likwidację żydów wewnątrz domu.

Ponieważ nie chciano ich wpuścić do mieszkania, dwaj członkowie ze „Żbika” wtargnęli przez okno i otworzyli drzwi do sieni, którymi wszedł Bolesław Krzyszkiewicz i Ż. a w chwilę po tym wezwany do środka Andrzej W.. Ten ponieważ nie posiadał własnej broni, wziął karabin od Mariana G. i udał się do domu. 
W mieszkaniu była obecna tylko żona Franciszka Szycha i sterroryzowana bronią wskazała komorę jako miejsce ukrywania się żydów. Istotnie w mieszkaniu tym od dłuższego czasu ukrywała się grupa osób narodowości żydowskiej przed zagładą ze strony okupanta.

Po otwarciu komory i oświetleniu jej lampką elektryczną stwierdzono obecność jednego żyda i wówczas Krzyszkiewicz Bolesław wydał rozkaz ogniowy, który wykonał Bolesław Ż, kładąc trupem żyda na miejscu.

Pozostałym polecono wyjść do sieni, gdzie przeprowadzono rewizję. W wyniku rewizji, broni u nich nie znaleziono ani też nie znaleziono jej w mieszkaniu.

Jak wynika z meldunku Bolesława Krzyszkiewicza o tej akcji /k.10/ w czasie rewizji znaleziono u tych ludzi pieniądze, zegarki i pierścionki oraz garderobę osobistą, które zabrano.

Mimo stwierdzenia, że ludzie ci należą do osób ukrywających się przed Niemcami i mimo stwierdzenia, że broni nie posiadają i grabieżą się nie trudnią a jedynie pozostają w ukryciu, oskarżony Krzyszkiewicz Bolesław nie odstapił od wykonania zbrodniczego jak się naocznie przekonał rozkazu a za nim poszła reszta uczestników i ustawiwszy żydów twarzą do ściany, Krzyszkiewicz Bolesław każdemu z obecnych wyznaczył ofiarę, poczym dał hasło do strzału i ludzi tych pozbawiono życia.

Po dokonaniu zbrodni napastnicy opuścili mieszkanie polecając gospodarzom zatarcie śladów zbrodni i na polu Krzyszkiewicz Bolesław zakończył akcję polecając reszcie rozejść się do domu i wezwał uczestników do zachowania tajemnicy.

Po akcji Krzyszkiewicz Bolesław sporządził meldunek do komendy obwodu /k.10/.

Podejrzani za wyjątkiem Krzyszkiewicza Bolesława, który przyznał się do winy i w obronie swej podkreślił, że działał tylko dla celu wykonania rozkazu, nie przyznali się do winy, przyznając tylko faktyczny udział w akcji. Podkreślili oni, że o prawdziwym charakterze akcji nie byli poinformowani bądź w ogóle [Mieczysław L., Ignacy K., Marian G.] bądź, że chodzi o likwidację grupy napadającej ludność. [Andrzej W., Bolesław Ż.]

Te wyjaśnienia oskarżonych w świetle wyników przewodu sądowego na wiarę nie zasługują i należy twierdzić, że udając się na akcję bojową Krzyszkiewicz Bolesław musiał omówić zadanie akcji, a pod domem Szycha „na podstawie wyjściowej” omówić szczegółowy plan akcji, co też w istocie uczynił, wyznaczając ludzi do bezpośredniej akcji i do ubezpieczenia.

W świetle wyników przewodu sądowego wina oskarżonych została im udowodniona i uznana jako zbrodnia $\mathrm{z}$ art. 1 ust. 2 dekretu $\mathrm{z}$ dnia 31.VIII.44 r.

Odnośnie oskarżonych Krzyszkiewicza Bolesława, Andrzeja W. i Bolesława Ż. Sąd nie znalazł okoliczności które by uzasadniały odstapienie od ustawowego wymiaru kary, przyczym odnośnie osk. Andrzeja W. należy podkreślić, że wyjaśnienia jego złożone na rozprawie o samej akcji na wiarę nie zasługują. Jeśli się zważy, że oskarżony ten wezwany do wnętrza domu, zabrał od G. karabin i że jak na podstawie ustaleń śledztwa i rozprawy przyjać należy karabin ten był uszkodzony ale 
zdatny do oddania strzału, następnie z postawy zajętej przez tego oskarżonego wobec delikwentów, w konsekwencji należy przyjąć, że oskarżony chciał wykonać rozkaz Krzyszkiewicza Bolesława i z faktem tym godził się. I jest rzeczą obojętną czy $\mathrm{z}$ ręki jego zginął człowiek czy nie, faktem jest, że osk. W. na popełnienie zbrodni godził się.

Wszyscy trzej oskarżeni byli na miejscu zbrodni, bezpośrednio zetknęli się z ofiarami i osobiście stwierdzili, że rozkaz likwidacji opierał się co najmniej na fałszywych przesłankach.

Tłumaczenie się oskarżonych, że działali jako żołnierze w wykonaniu rozkazu w konfrontacji z rzeczywistością nie wytrzymują krytyki. Żołnierz jest obowiązany do wykonania rozkazu, lecz ma prawo i obowiązek odmówić wykonania rozkazu, który jest zbrodnią, lub w skutkach przynosi zbrodnię i oskarżony Krzyszkiewicz Bolesław stwierdziwszy na miejscu, że chodzi tu o ludzi ukrywających się tylko przed Niemcami, że ludzie ci broni nie posiadają i że wykonanie tego „rozkazu” jest niczym innym jak realizacją polityki eksterminacyjnej Niemców w stosunku do żydów, obowiązany był powstrzymać wykonanie „rozkazu” i to samo obowiązywało zarówno W. jak i Ż.

Odnośnie oskarżonych L., K. i G. Sąd uznał, że wymienieni wezwani zostali do akcji i zgodnie z dyscypliną wojskową do akcji się stawili, że zostali następnie błędnie poinformowani o istocie sprawy, że chodzi o likwidację żydów rabujących z bronią w ręku, że następnie wewnątrz domu nie byli i nie byli w możności stwierdzić, że założenie jest fałszywe i nie odpowiada prawdzie, że następnie bezpośredniego udziału w mordzie nie brali, po uwzględnieniu tych okoliczności Sąd uznał, że zachodzą podstawy do nadzwyczajnego złagodzenia kary i karę tę w sposób w sentencji ustalony im złagodził mając na uwadze zeznania świadków którzy w innych wypadkach podkreślili przejawy pozytywnej ich działalności.

Ponadto $\mathrm{w}$ toku postępowania sądowego na podstawie wyjaśnień oskarżonych ustalonym zostało, że w r. 1944 w rejonie Dosłonki pow. miechowskiego odbywały się ćwiczenia polowe grupy AK w której brali udział osk. Bolesław Krzyszkiewicz, Andrzej W., Mieczysław L. i inni uczestnicy pod dowództwem „Huberta”.

W czasie ćwiczeń porą nocną, gdy uczestnicy doszli do wsi Dosłonka, zarządzono przerwę ćwiczeń i odpoczynek. W czasie przerwy osk. Krzyszkiewicz otrzymał wiadomość, że w stodole u pewnego gospodarza ukrywa się żyd wobec czego udał się na miejsce i żyda tego zastrzelił.

Odmienne tłumaczenia tego oskarżonego $\mathrm{w}$ śledztwie na wiarę nie zasługują i na tle wyjaśnień oskarżonych W. i L. należy przyjąć, że obarczenie tą zbrodnią osk. Stanisława G. było chęcią zrzucenia z siebie odpowiedzialności.

Oskarżony G. do winy się nie przyznał, od początku twierdził, że wówczas w ćwiczeniach udziału nie brał a osk. W. stwierdził, że na odgłos wystrzału, gdy wraz z wieloma innymi pobiegł z ciekawości na miejsce, zobaczył wychodzącego ze stodoły osk. Krzyszkiewicza Bolesława oraz J., a w stodole zauważył leżącego na boisku człowieka. W toku rozprawy osk. Krzyszkiewicz Bolesław nie potwierdził zarzutów odnośnie osk. G. i Sąd osk. tego jak i pozostałych oskarżonych dla 
braku dowodów winy uniewinnił uznając, że czynu powyższego dopuścił się osk. Krzyszkiewicz Bolesław.

[...]

Orzeczenie o utracie praw i przepadku majątku jest ustawowym następstwem skazania za zbrodnię z dekretu sierpniowego a zwolnienie oskarżonych od kosztów postępowania jest dalszą tego konsekwencją.

Przewodniczący S.S.: A.B. Kobylarz [podpis]

Ławnicy: $\quad$ Franciszek Garło [podpis]

Witold Kielar [podpis]

Nr 6

\section{SENTENCJA WYROKU łącznego \\ W IMIENIU RZECZYPOSPOLITEJ POLSKIEJ}

Dn. 8. lutego $1952 \mathrm{r}$.

Sąd Wojewódzki w Krakowie w Wydziale IV Karnym w składzie następującym:

Przewodniczący S.S.: W. F. Bańbuła

$\begin{array}{ll}\text { Sędziowie } & \text { J. Biedroń } \\ \text { Lawnicy } & \text { S. Filek } \\ \text { Protokolant } & \text { S. Fiutakowa }\end{array}$

w obecności Prokuratora Wojew. A. Mizerski

rozpoznawszy dn. 8 lutego 1952 r. sprawę Bolesława Krzyszkiewicza urodz. 30 X 1913 r. w Czeladzi syna (córki) Jakuba i Marii Kupczyk

skazanego:

I. prawomocnym wyrokiem Wojskowego Sądu Rejonowego w Krakowie z dnia 12 IV 1950 r. Nr. akt Sr.187/50 za przestępstwo z art. 4 § 1 Dekretu z 13 VI 1946 r. na karę więzienia przez 10 /dziesięć/ lat z utratą praw publicznych i obywatelskich praw honorowych na czas lat 3 /trzech/.

II. wyrokiem Sądu Apelacyjnego w Krakowie z dnia 24 X 1950 r. Sygn. K.180/50 za przestępstwo z art. 1 ust. 1 Dekretu z 3181944 r. na karę śmierci oraz utratę praw publicznych i obywatelskich praw honorowych na zawsze i przepadek mienia, utrzymanego w mocy wyrokiem Sądu Najwyższego z dnia 3051951 r. Sygn. II k.368/51

III. decyzją Prezydenta R.P. z dnia 2881951 r. kara śmierci została zamieniona na karę dożywotniego więzienia

$$
\text { orzekł: }
$$

W miejsce kar orzeczonych powyższymi wyrokami wymierza Bolesławowi Krzyszkiewiczowi łączną karę dożywotniego więzienia i orzeka utratę praw publicznych i obywatelskich praw honorowych na zawsze oraz przepadek mienia.

Zwalnia Bolesława Krzyszkiewicza od uiszczenia opłaty sądowej i zwrotu kosztów postępowania. 
[podpis]

[podpis]

[podpis]

Odpisy otrzymuja

1) Krzyszkiewicz B. w więzieniu w Krakowie [skreślone: Wiśnicz Nowy]

2) Prok. Woj. do I S 50/50

Rob. 7 dni

[pieczęć] Wysłano dnia 19.III 26.III 1952 r.

[pieczęć] Kartę karną co do oskarż. Bolesława Krzyszkiewicza przesłano do Min. Spraw. Kr 22/I 57 [podpis]

\section{$\mathrm{Nr} 7$}

WYROK - ŁĄCZNY

W Imieniu Rzeczypospolitej Polskiej.

Dnia 8 lutego $1952 \mathrm{r}$.

Sąd Wojewódzki w Krakowie w Wydziale IV Karnym w składzie następującym:

Przewodniczący S.S.: W. F. Bańbuła

Ławnicy J. Biedroń

S. Filek

Protokolant S. Fiutakowa

w obecności Prokuratora Wojew. A. Mizerski

rozpoznawszy dn. 8 lutego 1952 r. sprawę Bolesława Krzyszkiewicza urodz. 30 X 1913 r. w Czeladzi syna Jakuba i Marii Kupczyk

skazanego:

I. prawomocnym wyrokiem Wojskowego Sądu Rejonowego w Krakowie z dnia 12 IV 1950 r. Nr. akt. Sr.187/50 za przestępstwo z art. 4 § 1 Dekretu z 13 VI 1946 r. na karę więzienia przez 10 /dziesięć/ lat z utratą praw publicznych i obywatelskich praw honorowych na czas lat 3 /trzech/.

II. wyrokiem Sądu Apelacyjnego w Krakowie z dnia 24 X 1950 r. Sygn. K.180/50 za przestępstwo z art. 1 ust. 1 Dekretu z 3181944 r. na karę śmierci oraz utratę praw publicznych i obywatelskich praw honorowych na zawsze i przepadek mienia, utrzymanego w mocy wyrokiem Sądu Najwyższego z dnia 3051951 r. Sygn. II K.368/51

III. decyzją Prezydenta R.P. z dnia 2881951 r. kara śmierci została zamieniona na karę dożywotniego więzienia

orzekł:

W miejsce kar orzeczonych powyższymi wyrokami wymierza Bolesławowi Krzyszkiewiczowi łączną karę dożywotniego więzienia i orzeka utratę praw publicznych i obywatelskich praw honorowych na zawsze oraz przepadek mienia. 
Zwalnia Bolesława Krzyszkiewicza od uiszczenia opłaty sądowej i zwrotu kosztów postępowania.

\title{
UZASADNIENIE
}

Niniejszy wyrok łączny Sąd orzekł na zasadzie art. 35 kk. Wymienione bowiem w sentencji wyroki, już prawomocne, $z$ uwagi na czas popełnienia przez skazanego czynów tymi wyrokami mu przypisanych - uzasadniając w pełni w oparciu o przepis art. 31-35 k.k. Przy wydaniu wyroku łącznego Sąd uwzględnił w całości motywy podniesione przez Sądy w sprawach rozpatrywanych i orzekł karę łączną dożywotniego więzienia w granicach wyżej powołanych przepisów ustawy.

Inne orzeczenia sąd oparł na znanych przepisach prawnych.

Przewodniczący

Fr. Bańbuła [podpis]

Ławnicy:

J. Biedroń [podpis]

S. Filek

\section{Słowa kluczowe}

Armia Krajowa, Miechów, Generalna Gubernia, Żydzi, morderstwa

\begin{abstract}
In late November 1943, in Rędziny-Borek near Miechów, a group of armed men, barged into the house of a local peasant, and from a hidden chamber dragged out six Jews hiding there. Then, having searched them thoroughly, and having taken away their valuables and cash, the victims were lined up against the wall and - one by one shot in the back of the head. The crime, however, was not perpetrated by bandits of some unidentified "forest people", but a carefully planned (and authorized by the District command) military operation of the Miechów Home Army structures.
\end{abstract}

\section{Key words}

Home Army (Armia Krajowa), Miechów, General Government, Jews, murders 